\title{
Three lichen species of Micarea (Pilocarpaceae) new to Belarus
}

\author{
Andrei Tsurykau 1*, Paweł Czarnota ${ }^{2}$ \\ 'Department of Biology, F. Skorina Gomel State University, Sovetskaja 104, 246019 Gomel, Belarus \\ ${ }^{2}$ Department of Agroecology, University of Rzeszów, Ćwiklińskiej 2, 35-601 Rzeszów, Poland
}

\section{Abstract}

Micarea elachista, M. micrococca and M. misella are reported for the first time from Belarus. Their phenotypic characters, distribution and ecological preferences are given.

Keywords: Ascomycota; lichenized fungi; crustose lichens; biodiversity; pine forest; Gomel region

\section{Introduction}

The genus Micarea was described by Fries [1] to accommodate a crustose species with a green granular thallus and convex immarginate apothecia named $M$. prasina Fr. Currently the genus comprises ca. 100 species [2,3] and is considered to be polyphyletic combining a large number of phenotypically variable species, as well as a heterogeneity of infrageneric characters $[4,5]$. Further studies will probably provide stronger support for the delimitation of at least some distinct phylogenetic lineages obtained by Andersen and Ekman [5] and based on mtSSU sequences, will legitimate descriptions of several new genera. Some steps towards a new nomenclature of these species have recently started, with Harris [6] transferring Micarea erratica (Körb.) Hertel, Rambold \& Pietschm. into the new genus Leimonis R.C. Harris, and Ekman and Svensson [7] introducing the genus Brianaria S. Ekman \& M. Svensson for species of the former Micarea sylvicola group.

Nearly 60 species of Micarea s.lat. are currently known from Europe (e.g. [2,8-13]), of which only 10 have been reported from Belarus, namely M. cinerea (Schaer.) Hedl.,

\footnotetext{
* Corresponding author. Email: tsurykau@gmail.com
}

Handling Editor: Maria Rudawska 
M. denigrata (Fr.) Hedl., M. erratica, M. lynceola (Th. Fr.) Palice, M. melaena (Nyl.) Hedl., M. nitschkeana (Lahm ex Rabenh.) Harm., M. peliocarpa (Anzi) Coppins \& R. Sant., M. prasina, M. sylvicola (Flot.) Vězda \& V. Wirth, M. tuberculata (Sommerf.) R.A. Anderson [14-16]. However, M. lynceola was reported at the beginning of the 20th century [17] and never confirmed. Furthermore, since the specimens of $M$. prasina were neither tested by TLC nor critically re-examined, this species should be widely treated in the country as M. prasina s.lat. Hence, our knowledge of Micarea in Belarus is still far from complete.

During a recent fieldwork in the Gomel region in southeastern Belarus, three Micarea species new to the country were discovered and details of these records are presented here.

\section{Material and methods}

The lichen biota of 14 study plots established in 2011-2013 in different types of Scots pine forests were investigated; these were selected to represent: Cladonia-type, Calluna vulgaris-type, Vaccinium vitis-idaea-type, Pleurozium schreberi-type, Pteridium aquilinumtype, Vaccinium myrtillus-type, Oxalis acetosella-type, Polytrichum commune-type and Ledum palustre-type stands. The size of each plot was limited by forest sub-blocks and occupied 2-12 ha. In each plot, 10 trees were randomly selected and all lichens were registered within them. Secondary chemistry of the sorediate crustose lichens was analyzed by thin-layer chromatography (TLC) in solvent $\mathrm{C}$ according to the methods of Orange et al. [18].

Voucher specimens are deposited in the Belarusian Polesye Scientific Herbarium of Francisk Skorina Gomel State University (GSU) and the collection of Micarea elachista in the Herbarium of the Gorce National Park (GPN).

\section{Results and discussion}

\section{Micarea elachista (Körb.) Coppins \& R. Sant., Bull. Br. Mus. nat. Hist., Bot. 11(2): 131 (1983)}

Thallus composed of corticate small warts, pale greenish-grey with numerous immersed or emergent, widely opened pycnidia which are a slightly darker than the thallus. Mesoconidia ellipsoid, 3.5-4.5 × 1.2-1.5 $\mu \mathrm{m}$. Apothecia very rare, globose, brown, immarginate with Elachista-brown pigment ( $\mathrm{K}+$ dissolving and fading into solution) in upper part of the hymenium. Ascospores 1-septate, oblong-fusiform, slightly curved, $10-15 \times 2-3 \mu \mathrm{m}$. No substances detected by TLC.

HABITAT. Micarea elachista was found in old-growth Vaccinium myrthillus-type pine forest on the bark of two Pinus sylvestris L. trees. The sample plot contained some boggy areas with Ledum palustre and Sphagnum spp. and was untypical of "Pinetum myrtillosum" in terms of the degree of humidity. Micarea elachista occurred together with Chaenotheca spp., Chaenothecopsis pusilla (Ach.) A.F.W. Schmidt, Cladonia spp., Hypocenomyce scalaris (Ach. ex Lilj.) M. Choisy (often supporting Clypeococcum hypocenomycis D. Hawksw.), Hypogymnia physodes (L.) Nyl., Lecanora compallens van Herk \& Aptroot, Lecidea nylanderi (Anzi) Th. Fr., Lepraria spp., Micarea denigrata (Fr.) Hedl., M. melaena (Nyl.) Hedl. and M. micrococca (Körb.) Gams ex Coppins. 
Coppins [19] showed M. elachista to be a predominantly lignicolous species in Europe colonizing decorticate trunks or large stumps of old trees, but Czarnota [10] has also reported it frequently on the bark of Pinus sylvestris in NE Poland.

GENERAL DISTRIBUTION. The lichen is distributed in boreal and temperate Europe, occurring in countries neighboring Belarus - Lithuania [20], Poland [10] and adjacent regions of Russia [21], as well as in North America [2] and Asia [21,22].

SPECIMEN EXAMINED. Belarus, Gomel region, Gomel district: Pribor forest, 1.5 $\mathrm{km} \mathrm{SW}$ of Pribor village, $52^{\circ} 22^{\prime} \mathrm{N}, 30^{\circ} 45^{\prime} \mathrm{E}, 9$ Oct. 2012, leg. A. Tsurykau (GPN/7650).

\section{Micarea micrococca (Körb.) Gams ex Coppins, Checklist of Lichens of Great Britain and Ireland: 86 (2002)}

Thallus composed of bright to dull green granules (goniocysts) with numerous immersed, small, white pycnidia producing microconidia 5-7 $\times 0.8-1 \mu \mathrm{m}$. Apothecia usually present, whitish, translucent when wet, immarginate, up to $0.3 \mathrm{~mm}$ in diam. Apothecial section colorless. Excipulum strongly reduced. Ascospores 1-septate, ovoid to oblong, 8-12 $\times 3-4 \mu \mathrm{m}$. Substance detected by TLC: methoxymicareic acid.

NOTE. According to phylogenetic analysis, $M$. micrococca is a polyphyletic taxon. For almost 20 years prior to 2002, this group of taxa was included in M. prasina [23] despite their different chemistry [19]. However, the chemistry appeared to be a sufficiently diagnostic character in further studies and today the presence of methoxymicareic acid is the main feature distinguishing the $M$. micrococca complex from other members of the $M$. prasina group. Visual identification of $M$. micrococca s.str. is possible when it is fertile, since its apothecia are white or cream while other representatives of the M. micrococca complex have at least some greyish apothecia due to a trace of Sedifolia-grey pigment which turns $\mathrm{K} \pm$ violet and $\mathrm{C} \pm$ violet. The darkest morphs containing methoxymicareic acid may also belong to the recently separated $M$. byssacea (Th. Fr.) Czarnota, Guzow-Krzemińska \& Coppins which probably also occurs in Belarus since it is found in neighboring regions [11] (and Czarnota, unpublished data).

In Belarus, both $M$. micrococca s.str. and M. micrococca s.lat. represent two distinct lineages of the complex [11], but the description, habitat and list of collections below are only given for M. micrococca s.str.

HABITAT. The species was found exclusively on bark of $P$. sylvestris in three pine forest types, all of which were well-lit with a sufficient amount of moisture, ranging from the wet Polytrichum-type to the medium humid Pleurozium schreberi-type.

GENERAL DISTRIBUTION. It is difficult to evaluate the true world distribution of M. micrococca s.str. as representatives of the M. micrococca complex were critically revised only recently [11], but it has been reported so far from the Czech Republic, Estonia, Finland, Germany, Lithuania, Poland, Slovenia and Switzerland [11,24]. However, this corticolous lichen-forming fungus inhabiting acidic bark appears to be frequent in Europe especially within large more or less managed coniferous woodlands.

SPECIMENS EXAMINED. Belarus, Gomel region, Gomel district: Kalinino forest, 1.5 $\mathrm{km}$ E of Tereshkovichi village, $52^{\circ} 15^{\prime} \mathrm{N}, 30^{\circ} 59^{\prime} \mathrm{E}, 3$ Aug. 2011, leg. A. Tsurykau (GSU/1867); same forest, $1.3 \mathrm{~km} \mathrm{NE}$ of Tereshkovichi village, $52^{\circ} 15^{\prime} \mathrm{N}, 30^{\circ} 58^{\prime} \mathrm{E}, 2$ Oct. 2012 , leg. A. Tsurykau (GSU/1868); Pribor forest, $0.5 \mathrm{~km} \mathrm{~S}$ of Pribor village, $52^{\circ} 23^{\prime} \mathrm{N}, 30^{\circ} 47^{\prime} \mathrm{E}, 10$ Oct. 2012, leg. A. Tsurykau (GSU/1869); same forest, $1.5 \mathrm{~km} \mathrm{SW}$ of Pribor village, $52^{\circ} 22^{\prime} \mathrm{N}$, $30^{\circ} 45^{\prime} \mathrm{E}, 10$ Oct. 2012, leg. A. Tsurykau (GSU/1870). 


\section{Micarea misella (Nyl.) Hedl., Bih. K. svenska Vetensk Akad. Handl. 18(3): 78 (1892)}

Thallus inconspicuous, partially on pine bark as a thin algal film, and partially on the thallus of M. denigrata. Pycnidia numerous, black, stalked, containing Sedifolia-grey pigment, $\mathrm{K}+$ violet, $\mathrm{C}+$ violet. Mesoconidia simple, cylindrical, 5.0-5.5 × 1.4-1.6(-1.9). Apothecia absent in Belarusian material. No substances detected by TLC.

HABITAT. The species was collected in young Vaccinium vitis-idaea-type pine forest growing on the edges of bark plates in bark fissures of Scots pine. Kotlov [25] noted that Micarea misella is exclusively lignicolous in Russia, and Coppins [26] noted that it is almost always lignicolous and rarely grows on the bark of old trees.

GENERAL DISTRIBUTION. Micarea misella is reported from Europe and North America, as well as from South America [2] and the Asian part of Russia [21]. Amongst neighboring countries, it occurs in Lithuania [20], Ukraine [27] and in adjacent regions of Russia [21], and in Poland [10] it is one of the commonest representatives of the genus.

SPECIMEN EXAMINED. Belarus, Gomel region, Gomel district: Staro-Djatlovichskoje forest, $2 \mathrm{~km}$ SW of Staryje Djatlovichi village, $52^{\circ} 13^{\prime} \mathrm{N}, 30^{\circ} 49^{\prime} \mathrm{E}, 1$ Aug. 2013, leg. A. Tsurykau (GSU/1763).

\section{Acknowledgments}

We are very grateful to the two anonymous reviewers for valuable comments on the manuscript, and especially to Professor Mark Seaward (Bradford) for his linguistic corrections and other improvements.

\section{Authors' contributions}

The following declarations about authors' contributions to the research have been made: field research and draft of the manuscript: AT; species identification and critical revising: PC; final writing of the manuscript: AT, PC.

\section{References}

1. Fries EM. Systema orbis vegetabilis. Lund: 1825.

2. Coppins BJ. Micarea Fr. (1825). In: Smith CW, Aptroot A, Coppins BJ, Fletcher A, Gilbert OL, James PW, et al., editors. The lichens of Great Britain and Ireland. London: British Lichen Society; 2009. p. 371-384.

3. Index Fungorum database [Internet]. 2014 [cited 2014 May 23]; Available from: http://www.indexfungorum.org

4. Czarnota P. New and some rare species of the genus Micarea (Micareaceae) in the lichen flora of Poland. Pol Bot J. 2004;49(2):135-143.

5. Andersen HL, Ekman S. Disintegration of the Micareaceae (lichenized Ascomycota): a molecular phylogeny based on mitochondrial rDNA sequences. Mycol Res. 2005;109(1):21-30. http://dx.doi.org/10.1017/ S0953756204001625

6. Harris RC. Four novel lichen taxa in the lichen biota of eastern North America. Opusc Philolichenum. 2009;6:149-156.

7. Ekman S, Svensson M. Brianaria (Psoraceae), a new genus to accommodate the Micarea sylvicola group. Lichenologist. 2014;46(03):285-294. http://dx.doi.org/10.1017/S0024282913000613

8. Coppins B. Micarea confusa: a new species from zinc- and cadmium-contaminated soils in Belgium and The Netherlands. Lichenologist. 1995;27(2):81-90. http://dx.doi.org/10.1006/lich.1995.0007

9. Printzen C. Die Flechtengattung Biatora in Europa. Biblioth Lichenol. 1995;60:1-275.

10. Czarnota P. The lichen genus Micarea in Poland. Pol Bot Stud. 2007;23:1-199.

11. Czarnota P, Guzow-KrzemińSka B. A phylogenetic study of the Micarea prasina group shows that Micarea micrococca includes three distinct lineages. Lichenologist. 2010;42(01):7. http://dx.doi.org/10.1017/ S0024282909990211 
12. Sérusiaux E, Brand AM, Motiejunaite J, Orange A, Coppins BJ. Lecidea doliiformis belongs to Micarea, Catillaria alba to Biatora, and Biatora ligni-mollis occurs in Western Europe. Bryologist. 2010;113(2):333-344. http://dx.doi.org/10.1639/0007-2745-113.2.333

13. Svensson M, Thor G. Micarea capitata, a new bryophilous lichen from Sweden. Lichenologist. 2011;43(05):401-405. http://dx.doi.org/10.1017/S0024282911000338

14. Bely P. Annotirovannyi spisok lishajnikov i likhenofil'nykh gribov elovykh ekosistem Belarusi. Osobo okhraniaemyie prirodnyie territorii Belarusi. Issledovaniya. 2011;6:146-178.

15. Yurchenko EO, Osipov AA, Shumeiko AM, Dovgailo KE. Lichens of Belarus: an illustrated electronic handbook. Minsk: K.E. Dovgailo; 2011.

16. Yatsyna AP. Novyie i interesnyie nakhodki lishajnikov i nelikhenizirovannykh gribov v Belarusi. Vesn Vitsebskaga Dziarzhaunaga Univ. 2012;5:45-49.

17. Bachmann E, Bachmann F. Litauische Flechten. Hedwigia. 1920;61(6):321-342.

18. Orange A, James PW, White FJ. Microchemical methods for the identification of lichens. London: British Lichen Society; 2001.

19. Coppins BJ. A taxonomic study of the lichen genus Micarea in Europe. Bull Br Mus Nat Hist Bot. 1983;11:17-214.

20. Motiejūnaitè J. Checklist of lichens and allied fungi of Lithuania. Bot Lith. 1999;5(3):251-269.

21. Urbanavichus GP. A checklist of the lichen flora of Russia. Saint Petersburg: Nauka; 2010.

22. Joshi Y, Nguyen TT, Wang XY, Lökös L, Koh YJ, Hur J-S. Contribution to the lichen mycota of South Korea. Mycotaxon. 2011;116(1):61-74. http://dx.doi.org/10.5248/116.61

23. Coppins BJ. Checklist of lichens of Great Britain and Ireland. London: British Lichen Society; 2002.

24. Mayrhofer H, Coppins BJ. Remarkable records of lichenized fungi from Slovenia. Herzogia. 2013;26(1):201206. http://dx.doi.org/10.13158/heia.26.1.2013.201

25. Kotlov YV. Semeistvo Micareaceae Vězda ex Hafellner - Mikareievyie. In: Golubkova NS, editor. Opredelitel' lishajnikov Rossii. 7. Lecideaceae, Micareaceae, Porpidiaceae. Saint Petersburg: Nauka; 1998. p. 98-118.

26. Coppins BJ. Two new species of Micarea from South Africa. Lichenologist. 1999;31(06):559. http://dx.doi. org/10.1017/S0024282999000730

27. Kondratyuk SY, Dymytrova LV, Nadyeina OV. The third checklist of lichen-forming and allied fungi of Ukraine. In: Kondratyuk SY, Roms OG, editors. Flora Lišajnikiv Ukraini. Kiev: Naukova Dumka; 2010. p. 446-486. (vol 2 pt 3). 